The current issue and full text archive of this journal is available on IHTIFAZ at : https://doi.org/10.12928/ijiefb.v2i2.856

\title{
Analisis Konsep Highest and Best Use Untuk Tanah Wakaf Menurut Perspektif Islam
}

\author{
Adelita Fitriani Baiq Rizki Pratama ${ }^{*}$ \\ ${ }^{1}$ Islamic Economic, Center of Religious and Cultural Studies \\ Postgraduate School Universitas Gadjah Mada \\ *e-mail: adelitafitriani@gmail.com
}

\begin{abstract}
The purpose of this paper is to offer a Highest and best use concept in Islamic perspective for waqf land. This study uses study literature, conceptual approach and critical analysis based on cross-disciplinary study, Highest \& best use analysis and Waqf concept, to construct a new method for analyzing the best land use decision in Islamic perspective for waqf land. This study found that $H B U$ is can not to be applied for analyzing waqf land use decision because in $\mathrm{HBU}$ method still use elements that are forbidden in Islamic Principles. As for the difference between the two forms of this method lies in the physical aspect and location, researchers added alternative guidelines for use of the Waqf land based on its location. On the legality aspect, researchers replace the indicators of assessment of land rights status based on the existence of the Waqf pledge (Ikrar) and the Waqf land certificate, on the zoning indicator, researchers added 5 sub-indicators to consider, namely Waqf land allocation, the form of rulings done in utilizing the land of Waqf, community needs, benefits that can be given and Ibdal/Istibdal. In financial aspects, the difference lies in the expenditure indicator (the evasion consideration for the zakat, infaq and sadhaqah fund) and the investment feasibility test using the gold value method and the gold index method. As for the best aspect of determining the use based on the maslahah aspect and property value calculation is grounded in the percentage of gold price increases.
\end{abstract}

Keywords: Highest and Best Use, Islam, Land, Waqf

\section{Abstrak}

Penelitian ini bertujuan untuk membuat konsep penilaian pemanfaatan terbaik (Highest and Best Use) dalam perspektif Islam yang digunakan pada tanah wakaf. Penelitian ini menggunakan studi literature dan pendekatan konseptual serta analisis kritis untuk membuat metode baru yang dapat digunakan dalam menganalisa pemanfaatan terbaik dari tanah wakaf. Hasil penelitian

Ihtifaz: Journal of Islamic Economics, Finance, and Banking

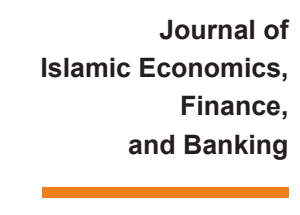

Vol. 2, No. 2, Desember 2019 , pp. 157-176, ISSN p:2622-4755 e:2622-4798

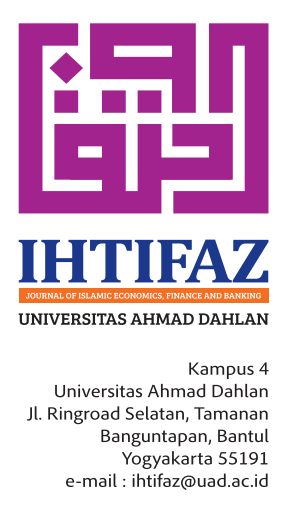


menemukan bahwa metode HBU tidak dapat diaplikasikan untuk menilai tanah wakaf dikarenakan terdapat beberapa elemen di dalamnya yang tidak IHTIFAZ - JIEFB sesuai dengan prinsip syariat Islam. Adapun perbedaan diantara kedua bentuk metode ini, yaitu pada aspek fisik dan lokasi, peneliti menambahkan pedoman alternatif penggunaan tanah wakaf berdasarkan lokasinya. pada aspek legalitas, peneliti mengganti indikator penilaian status hak atas tanah didasarkan pada keberadaan akta ikrar wakaf dan sertifikat tanah wakaf, pada indikator zoning, peneliti menambahkan 5 sub indikator yang perlu dipertimbangkan, yaitu peruntukan tanah wakaf, bentuk muamalah yang dilakukan dalam memanfaatkan tanah wakaf, kebutuhan masyarakat, manfaat yang dapat diberikan dan ibdal/istibdal. Pada aspek keuangan, perbedaan terletak pada indikator pengeluaran (pertimbangan pengeluran untuk dana ZIS) dan uji kelayakan investasi menggunakan gold value method dan gold index method. Adapun pada aspek penentuan penggunaan terbaik di dasarkan pada aspek maslahan dan perhitungan nilai properti didasarkan pada prosentase kenaikan harga emas.

Kata Kunci: Highest and Best Use, Islam, Tanah, Wakaf

\section{PENDAHULUAN}

Indonesia adalah negara dengan jumlah penduduk muslim terbesar di dunia. Pada tahun 2015, tercatat bahwa total penduduk muslim Indonesia menyumbang $12,6 \%$ dari total seluruh penduduk muslim di dunia dan Pew Research Center mengestimasi bahwa penduduk muslim Indonesia akan tetap termasuk dalam posisi 10 negara dengan jumlah penduduk muslim terbesar di dunia pada tahun 2060 (Diamant, 2019). Sebagai Negara dengan jumlah penduduk muslim terbesar di dunia maka Indonesia memiliki potensi yang sangat besar dalam hal pelaksanaan pembangunan ekonomi dengan menggunakan instrumen pembangunan ekonomi dalam Islam, seperti wakaf. Menurut data statistik Direktorat Pemberdayaan wakaf Kementerian Agama Republik Indonesia (BWI,

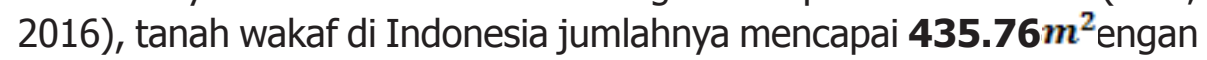
total luas keseluruhan tanah wakaf adalah 4.359.443.170 (atau setara dengan $\mathbf{4 3 6}$ ribu hektar). Sehingga dapat memberikan manfaat positif bagi pertumbuhan dan perkembangan perekonomian bangsa. Namun, harta wakaf di Indonesia berupa tanah dan peruntukannya antara lain untuk masjid $45 \%$, musolah $28,5 \%$, sekolahan $10,46 \%$, makam 4,66\%, Pesantren 3,07\% dan kegiatan sosial lainnya 8,3\% (Lihat gambar 1). Hal ini menunjukkan bahwa sebagian besar pemanfaatan tanah wakaf di Indonesia masih belum mengarah pada aplikasi yang produktif. 
Gambar 1. Penggunaan Tanah Wakaf

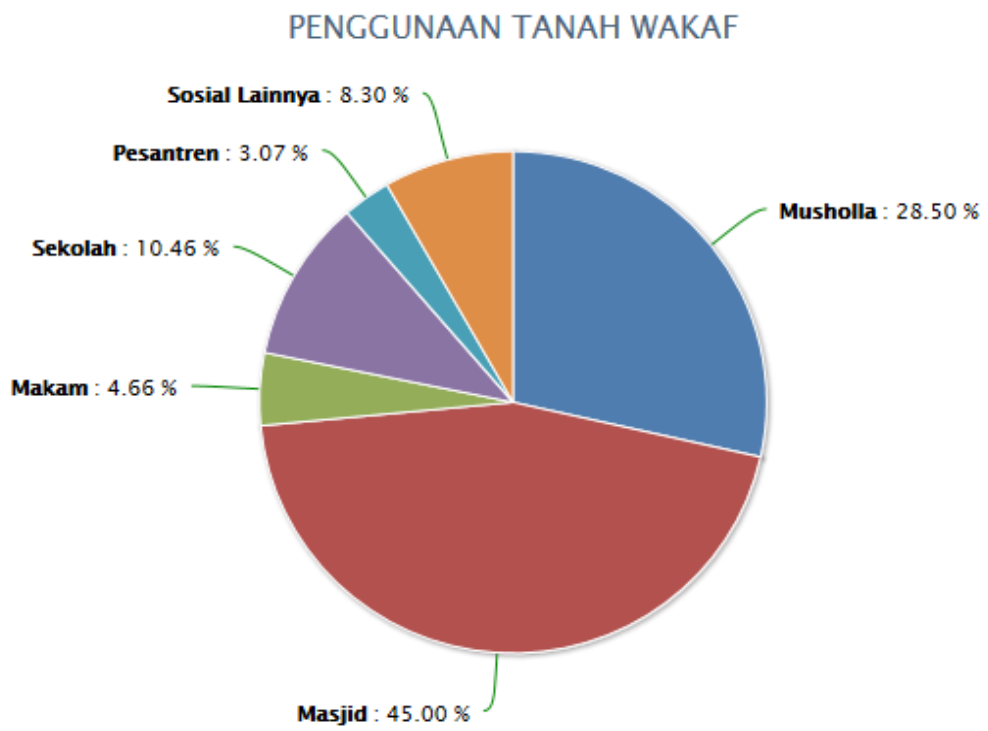

Journal of

Islamic Economics,

Finance,

and Banking

Vol. 2, No. 2, Desember 2019. pp. 157-176, ISSN p:2622-4755

Sumber: SIWAK, 2018

Maka dibutuhkan pembahasan lebih lanjut mengenai pemanfaatan yang terbaik agar tanah wakaf tersebut dapat memberikan manfaat sebesar-besarnya bagi kepentingan dan kesejahteraan umat. Untuk menentukan pemanfaatan terbaik dari suatu tanah wakaf maka perlu dilakukan penilaian terhadap asset tanah tersebut. Berdasararkan Standar Penilaian Indonesia (SPI) terdapat 10 prinsip penilaian properti, yaitu Highest and Best Use, Supply and Demand, Substitution, Anticipation, Change, Conformity, Competition, Increasing \& Decreasing Return, Externalities dan Contribution. Analisis data dapat dilakukan dengan 2 metode pendekatan, yaitu (1) Analisis Pasar yang digunakan untuk menilai permintaan dan penawaran serta studi pasar dan (2) Analisis Highest and Best Use (HBU) yang digunakan untuk menilai tanah kosong dan properti yang dikembangkan. Dengan merujuk pada SPI tersebut maka menurut penulis, metode terbaik untuk menilai pemanfaatan terbaik atas tanah wakaf yang belum diberdayakan dan belum maksimal pemberdayannya adalah metode pendekatan Highest and Best Use (HBU). Analisis Highest and Best Use harus memenuhi empat kriteria, yaitu legal permissibility, physical possibility, financial feasibility, dan maximum profitability (Appraisal Institute, 2008). Pernyataan positif tentang konsep dari Grissom dan Liu (1994) adalah konsep yang ditegakkan oleh hukum yang memungkinkan standar komparatif untuk membuat keputusan nilai real estat. Konsep ini berkaitan dengan proses mengidentifikasi kendala hukum, fisik, dan pasar pada properti oleh penilai. Namun, terdapat beberapa elemen penilaian dalam metode ini yang tidak sesuai dengan syariat Islam sehingga dibutuhkan metode tersendiri yang sesuai dengan syariat Islam. Oleh karena itu, penelitian 
ini dilakukan untuk membuat metode penilaian pemanfaatan terbaik atas tanah wakaf yang sesuai dengan syariat Islam dengan menggabungkan konsep Highest and Best Use (HBU) dengan ketentuan prinsip Islam yang mengatur perwakafan, sehingga dapat digunakan untuk menilai penggunaan terbaik atas tanah wakaf.

\section{LITERATURE REVIEW}

Berdasarkan yang diketahui penulis, telah terdapat beberapa penelitian sebelumnya yang dilakukan disejumlah tempat berkaitan dengan wakaf dan Highest and Best Use, peneliti gunakan sebagai sumber informasi dan bahan acuan yang berguna. Penelitian tentang manajemen wakaf produktif suatu lembaga pengelola wakaf telah dilakukan oleh beberapa peneliti sebelumnya, diantaranya adalah Rozalinda (2015), Gunawan Aji (2013), Mubarok (2013) dan Omar, dkk (2013). Keempat peneliti ini menggunakan metode penelitian kualitatif, dua diantaranya menggunakan pendekatan deskriptif yang dipadukan dengan analisis holistic dan analisis pada aspek pemasaran dan finansial lembaga yang bersangkutan. Penelitian wakaf yang lain berkaitan dengan potensi wakaf tanah di Indonesia dan pengembangan model pengelolaan yang dapat meningkatkan produktifitas tanah wakaf, telah dilakukan oleh beberapa peneliti termaksud diantaranya adalah Puspitasari (2017), Bismi Khalidin, dkk (2015), Suparman Ibrahim \& Nani Al-Mu'in (2011), Ali, Ahmad, \& Mahdzan (2015), Mohammad, Iman, \& Omar (2005), Mokhtar \& Ibrahim (2006) dan Pitchay, dkk (2018). Puspitasari membahas pemanfaatan tanah wakaf produktif dengan sistem muzara'ah untuk meningkatkan kesejahteraan para petani, Bismi Khalidin, dkk membahas prospek pemanfaatan tanah wakaf di Aceh untuk sektor pendidikan dan Suparman membahas potensi memproduktifkan tanah wakaf di Indonesia melalui pembangunan rumah sakit, perkantoran, usaha pertanian, pendirian bank, pendirian pabrik, dan sekolah. Meskipun Suparman tidak membahas secara mendetail prosedur dan cara yang perlu dilakukan nadzhir untuk memproduktifkan tanah wakaf, Suparman hanya menjabarkan bentukbentuk pengelolaan yang memungkinkan untuk memproduktifkan tanah wakaf. Adapun peneliti lainnya yang telah disebutkan mengembangan model wakaf yang dipadukan dengan metode pembiayaan keuangan melalui lembaga keuangan, seperti Murabahah, Istishna', Salam, Ijarah thumma bai', Mersad (Build Sale and leaseback), joint venture (mudharabah dan musharakah), public issue/equipment participation (mudharabah equity dan musharakah equity), Islamic bonds (sukuk) dan wakaf saham. Penelitian-penelitian ini menggunakan metode penelitian kualitatif dalam penelitiannya.

Adapun penelitian terdahulu tentang definisi HBU telah dilakukan oleh Graaskamp (1978) yang mempelopori alternatif definisi dari HBU, yaitu Most Probable Use atau Most Fitting Use. Kemudian definisi HBU disempurnakan dalam penelitian Kinnard (1966). Kemudian penelitian 
yang mengkritik konsep HBU dilakukan oleh Vandell (1982), Grissom (1986), Graaskamp (1979), Kinnard (1966), Wendt (1972), dan Pearson (1985) bahwa sejauh ini penggunaan konsep HBU hanya dipandang sebagai suatu proses dan bukan sebagai suatu model formal. Penelitian Dotzour, dkk (1990) membentuk model formal dari HBU agar konsep ini dapat memberikan analisis yang konsisten dengan menambahkan variabel keuangan dan lokasi ke dalam analisis HBU yang sebelumnya hanya berupa aspek fisik, hukum, infrastruktur, dan parameter pasar. Penelitian sebelumnya tentang HBU hampir tidak ada hubungannya dengan kepentingan masyarakat, studi ini hanya menawarkan model normatif yang berfokus pada masalah kesetaraan ekonomi (Dotzour et al., 1990). Ini menunjukkan bahwa konsep HBU masih terlihat sebagai elemen subjektif dari penilai.

Berdasarkan pemaparan di atas, perbedaan penelitian ini dengan penelitian sebelumnya terletak pada pengembangan metode analisis Tertinggi dan Penggunaan Terbaik berdasarkan ketentuan Prinsip Islam (HBU-I) untuk mengetahui pemanfaatan terbaik tanah wakaf sehingga dapat menjadi produktif untuk kepentingan umat. Perbedaan lain terletak pada objek penilaian bahwa HBU-I hanya digunakan untuk menilai tanah wakaf.

\section{WAKAF TANAH}

Wakaf sering diartikan sebagai suatu perbuatan menahan harta sehingga dapat diambil manfaat sebanyak-banyaknya demi kepentingan umum dalam rangka mendekatkan diri kepada Allah SWT serta untuk kemaslahatan orang banyak. Kegiatan wakaf menunjukkan bahwa pemanfaatan yang dimaksud disini adalah pengelolaan yang diperbolehkan dan riil, atau pengelolaan revenue (penghasilan) barang tersebut untuk tujuan kebajikan (Zuhaili, 2011: 271). Wakaf juga berarti sebagai pranata keagamaan dalam Islam yang memiliki hubungan langsung secara fungsional dengan upaya pemecahan masalahmasalah sosial dan kemanusiaan, seperti pengentasan kemiskinan dan pemberdayaan ekonomi umat (Rozalinda, 2015). Oleh karenanya, wakaf disebut sebagai salah satu instrument pembangunan dalam ekonomi Islam.

Adapun, wakaf tanah merupakan salah satu bentuk wakaf benda tidak bergerak. Sehingga, wakaf tanah didefinisikan sebagai perbuatan mewakafkan tanah oleh waqif dengan tujuan agar tanah tersebut dapat dimanfaatkan untuk kepentingan umat. Hukum wakaf tanah (terutama hak-hak atas tanah) tidak bisa dilepaskan dari politik hukum pertanahan karena pada dasarnya, tanah dikuasai oleh negara dan dimanfaatkan sebesar-besarnya untuk kemaslahatan masyarakat. Oleh karena itu, wakaf tanah sebagai institusi keagamaan diharapkan dapat mengisi dan membantu negara untuk memakmurkan dan atau menyejahterakan masyarakat Indonesia (Mubarok, 2008). 
Tanah wakaf dapat berguna untuk membantu kepentingan (kesejahteraan) umum apabila ikrar wakif untuk kepentingan ibadah 'ammah, bukan ibadah mahdloh. Sehingga pemanfaatan dan pemberdayaan tanah wakaf bisa dilakukan secara produktif. Pemahaman dan pengetahuan masyarakat yang masih minim dalam pemanfaatan wakaf tanah yang produktif menyebabkan banyak dari masyarakat yang melakukan wakaf dengan peruntukan sebagai ibadah mahdloh semata serta tidak memenuhi persyaratan undang-undang yang berlaku, seperti pembuatan sertifikat tanah wakaf dan pendaftarannya sebagai asset wakaf di Badan Wakaf Indonesia. Hal ini menyebabkan sering terjadinya konflik kepemilikan atas tanah yang diklaim oleh ahli waris karena tidak adanya penguatan dari sisi legalitas hukumnya. Sehingga pengutan dari sisi hukum juga perlu diperhatikan.

Pemanfaatan dan pemberdayaan tanah-tanah wakaf yang harus diprioritaskan adalah tanah-tanah wakaf yang memiliki potensi ekonomi yang besar, yaitu tanah-tanah yang berlokasi strategis secara ekonomis, seperti di pinggir jalan, pasar atau tempat keramaian lainnya. Sebab setiap lokasi memiliki karakteristiknya masing-masing termaksud budaya dan kebiasaan masyarakat juga dapat menjadi pertimbangan yang perlu diperhatikan dalam menggunakan tanah wakaf. Meskipun, model-model pemberdayaan yang produktif belum banyak dilakukan. Selain itu, tanah wakaf yang berada di tempat yang kurang strategis dan tidak lagi dapat digunakan sebagaimana peruntukan walanya bisa dilakukan Ibdāl dan istibdāl (penukaran) agar tanah tersebut dapat memberikan hasil yang lebih maksimal.

\section{HIGHEST AND BEST USE MENURUT PERSPEKTIF ISLAM (HBU-I)}

Highest and Best Use (HBU) adalah penggunaan yang paling mungkin dan optimal dari suatu aset, yang secara fisik dimungkinkan, telah dipertimbangkan secara memadai, secara hukum diizinkan, secara finansial layak, dan menghasilkan nilai tertinggi dari aset tersebut (SPI, 2015). Namun terdapat banyak konflik dalam pengembangan model penggunaan lahan (Grissom, 1986 dan Vandell, 1982) dan ambiguitas dalam konsep ini dapat terjadi bila tidak memperhatikan relevansinya dengan literature lain, seperti ekonomi, keuangan dan studi lain yang berhubungan dengan keputusan penggunaan tanah dan penilaian. Sebab, HBU mulanya hanya dipandang sebagai suatu proses dan bukan sebagai suatu model formal (Vandell:1982, Grissom:1986, Graaskamp:1979, Kinnard:1966, Wendt:1972, dan Pearson:1985 dikutip Dotzour, dkk: 1990). Sehingga Dotzour, dkk (1990) membentuk model formal dari HBU agar konsep ini dapat memberikan analisis yang konsisten dengan mengidentifikasi berbagai asumsi dalam perdebatan model penggunaan tanah dan memasukkan asumsi-asumsi tersebut ke dalam model keputusan ekonomi formal. Penelitian Dotzour ini didasari oleh pemikiran Vandell mengenai konsistensi estimasi dari analisis dan 
pemikiran Dasso serta Woodward mengenai etika sosial dalam real estate dan perlunya efisiensi pasar real estate untuk alokasi sumber daya yang optimal. Sehingga terbentuknya model optimasi yang dibatasi secara formal untuk penggunaan tanah dengan menambahkan biaya modal (variabel keuangan) dan lokasi (ekologi social) dalam aspek fisik, hukum, infrastruktur dan parameter pasar. variabel keuangan dan lokasi tersebut diperlukan untuk memajukan paradigma penggunaan agar sesuai dengan konteks saat ini.

Dalam penelitian Dotzour, dkk (1990) telah disinggung bahwa penilaian HBU terhadap tanah didasarkan terhadap analisis ekonomi yang di buat oleh Von Thunen (1826) dan David Ricardo. Ricardo memfokuskan analisisnya pada fisik tanah dan atribut legal yang mengarah pada kemampuan properti dalam menghasilkan keuntungan dan masalah harga. Sedangkan Von Thunen lebih kepada analisis yang bersifat umum terhadap lokasi tanah (pola ekologi lahan), yaitu bagaimana kegiatan atau fasilitas di sekitar lahan dapat mempengaruhi kondisi dari lahan dari waktu ke waktu. Adapun Colwell (1988) meklasifikasikan kedua sudut pandangan ini secara lebih mendalam pada level mikro dan makro. Kedua klasifikasi Colwell ini mengidentifikasi dua perspektif dalam pengambilan keputusan terhadap penggunaan lahan, yaitu (1) maksimalisasi kekayaan individu dan (2) bertujuan untuk mensejahterakan masyarakat (kepentingan masyarakat). Dalam literatur-literatur penilaian, pembahasan mengenai parameter makro berdasarkan lokasi dan kepentingan masyarakat sangat sedikit bahkan hampir tidak dibahas. Saat kedua perspektif tersebut dibahas, literature penilaian menggabungkan kepentingan masyarakat sebagai sebuah kendala/pertimbangan bagi pilihan individu. Kendala-kendala tersebut adalah zoning, politik dan permasalahan legal.

Adapun kritik Graaskamp (Vandell dan Carter dalam Essay in Honor of James Graraaskamp, 2000) terhadap HBU mengarah pada alasan teoritis dan praktik. Teoritis, mengarah pada definisi HBU seharusnya diinterpretasikan dalam konteks most probable use atau most fitting use yang konsisten dengan definisi dari waktu. Konsep ini harus stokastik (menggabungkan unsur pertimbangan risiko dan ketidakpastian) dan dinamis (berkembangan dari waktu ke waktu). Perbedaan pendapat dan kritik mengenai istilah HBU sudah banyak terjadi, bahkan terdapat perbedaan penggunaan dibeberapa negara, di Amerika para penilai lebih menyukai istilah "the most probable use" sedangkan di Inggris lebih suka menggunakan istilah "highest and best use" (Prawoto, 2015). Sedangkan kritik Graaskamp dalam konteks praktik, yaitu HBU harus mewakili pelayanan terbaik bagi masyarakat dan tidak boleh ditafsirkan secara sempit yang hanya mengacu pada pasar swasta. Ini merupakan arahan pertimbangan bagi real estate dalam konteks barang publik. Graaskamp menginterpretasikan konsep HBU sebagai konsep yang berisi elemen manfaat sosial dibandingkan dengan manfaat pribadi. Demikianlah, proses terbentuknya HBU hingga diaplikasikan pada saat ini. 
Highest and Best Use berdasarkan ketentuan syariat Islam (HBU-I) adalah metode penilaian pemanfaatan terbaik atas suatu tanah wakaf baik berupa tanah kosong maupun tanah dengan properti pengembangan. Metode ini dikembangkan berdasarkan metode Highest and Best Use yang dipadukan dengan aspek syariat Islam. Pembahasan mengenai kesejahteraan masyarakat dalam konsep ini masih sedikit, bahkan konsep kesetaraan ekonomi yang ditawarkan didalamnya hanya bersifat normative (Dotzour, dkk: 1990). Berbeda dengan tujuan dari metode HBU-I yang menekankan kepada pemenuhan kebutuhan masyarakat dengan memaksimalkan penggunaan tanah wakaf melalui produktifitasnya sehingga hasilnya dapat digunakan untuk kesejahteraan/kepentingan masyarakat. Namun, terdapat batasanbatasan dalam pengelolaan lahannya agar tidak menyalahi syariat Islam dan mematikan kehidupan masyarakat sekitar.

Produktivitas maksimum yang dimaksud dalam metode HBU adalah menemukan alternatif penggunaan yang dapat memberikan hasil yang besar dan pada akhirnya dapat meningkatkan nilai tanah yang bersangkutan. Namun demikian, Islam sebagai agama yang sangat menjunjung maslahah umat tidak memandang suatu nilai hanya berdasarkan pada besarnya pendapatan atau penghasilan diukur dari satuan mata uang semata. Sebab orientasi dari terlaksananya suatu kegiatan muamalah tidak hanya pada aspek material duniawi melainkan juga menargetkan aspek spiritual yang bernilai ibadah dan berorientasi akhirat. Orientasi yang ditujukan pada kedua aspek ini berakhir pada tercapainya falah, yaitu kemenangan didunia dan diakhirat.

Pemanfaatan yang terbaik menurut Islam adalah pemanfaatan yang dapat memberikan kesejahteraan dan kebaikan bagi banyak pihak. Terutama wakaf sebagai instrument pembangunan dalam ekonomi Islam tentu tidak hanya menargetkan besarnya penghasilan yang dapat diperoleh tetapi juga besarnya kemaslahatan bagi umat. Dalam hal pemanfaatan terhadap tanah wakaf maka pemanfaatan yang terbaik adalah pemanfaatan yang menghasilkan namun tidak mematikan penghidupan masyarakat sekitar tanah tersebut melainkan dapat menghidupkan perekonomian dan membangun masyarakat.

Berikut, analisis terhadap aspek-aspek yang harus dipenuhi dalam metode $\mathrm{HBU}$ :

\section{Aspek Fisik dan Lokasi}

Dalam aspek ini, penilaian yang dilakukan meliputi bentuk dan luas lahan, lokasi, aksebilitas dan ketersediaan sarana publik. Lokasi memegang peran penting dalam pengembangan tanah wakaf sebab lokasi yang strategis memungkinkan pemanfaatan yang lebih profitable dibandingkan lokasi yang terpencil. Oleh karena itu, lokasi, ukuran tanah dan tipe/jenis tanah wakaf menjadi salah satu faktor permasalahan dalam pengembangan tanah wakaf (Ali; et al., 2015; Mokhtar \& Ibrahim, 2006). 
Tipe tanah wakaf dibedakan menjadi dua jenis, yaitu Wakaf Khas dan Wakaf 'Am. Wakaf Khas (specific) adalah tipe tanah wakaf yang saat diwakafkan disebutkan secara jelas pemanfaatan yang dikehendaki oleh waqif adapun Wakaf 'Am (general or philanthropic waqf) diserahkan penggunaannya kepada pengelola tanpa klasifikasi spesifik jenis penggunaan selama untuk kemaslahatan umat dan sesuai dengan shariat Islam. Dari kedua jenis wakaf ini dalam praktik perwakafan saat ini yang terjadi di Indonesia, masyarakat lebih mengenal jenis wakaf khas dan jumlahnya lebih dominan dibandingkan wakaf 'am, hal ini dapat dilihat berdasarkan jumlah pemanfaatan tanah wakaf yang lebih dominan dalam bentuk masjid dan mushollah. Meskipun tidak dapat dibuktikan secara pasti disebabkan keterbatasan data yang dihimpun oleh lembaga berwenang. Selain itu, menurut Mokhtar dan Ibrahim (2006) berdasarkan kedua jenis/tipe wakaf ini hanya wakaf 'am yang dapat dimanipulasi ke dalam bentuk penggunaan yang menghasilkan pendapatan.

Pada analisis lokasi lahan ditambahkan indikator penilaian yang didasarkan pada panduan bantuan pemberdayaan wakaf produktif berkaitan dengan jenis usaha yang dapat dikembangkan diatas tanah wakaf berdasarkan kategori lokasi tanah wakaf dalam tabel berikut:

Tabel 1. Model Jenis Usaha Berdasarkan Kategori dan Jenis Lokasi Tanah Wakaf

\begin{tabular}{lll}
$\begin{array}{c}\text { Kategori } \\
\text { Tanah }\end{array}$ & Jenis Lokasi Tanah & \multicolumn{1}{c}{ Jenis Usaha } \\
& Tanah persawahan & Pertanian \\
& Tambak ikan \\
& Tanah perkebunan & Perkebunan \\
& Home industry & Tempat wisata \\
& & Palawija \\
PEDESAAN & Tanah lading atau & Real estate \\
& padang rumput & Pertamanan \\
& & Home industry \\
& Tanah rawa & Perikanan \\
& Tanaman sayur \\
& Tempat wisata \\
& & Perkebunan \\
& Tanah perbukitan & Bangunan \\
& Home industry \\
& Penyulingan air \\
& minum \\
&
\end{tabular}


IHTIFAZ - JIEFB

\section{PERKOTAAN}

Dekat jalan tol
Tanah dekat/di dalam
perumahan

Tanah dekat keramaian
(pasar, terminal, stasiun
sekolah umum)

TEPI PANTAI

Pinggir laut

Rawa bakau
Perkantoran

Pusat perbelanjaan

Apartemen

Hotel/penginapan

Gedung pertemuan

Perkantoran

Pertokoan

Pusat perbelanjaan

Rumah sakit

Rumah makan

Sarana pendidikan

Hotel/penginapan

Apartemen, dll

Pom bensin

Bengkel

Rumah makan

Outlet

Warnet

Sarana pendidikan

Klinik

Apotek

Outlet

BMT

Pertokoan

Rumah makan

Bengkel

BPRS/BMT

Klinik

Jasa penitipan

Tambak ikan

Objek wisata

Hasil kerajinan

Perkebunan

Sumber: Panduan Bantuan Pemberdayaan Wakaf Produktif, 2008

Dari analisis fisik dan lokasi, penulis akan mengusulkan beberapa properti yang memungkinkan untuk dibangun diatas lokasi. Kemudian dilaksanakan analisis legal syari'i atas tanah secara keseluruhan dan secara spesifik dikaitkan dengan alternatif properti yang lolos analisis 
fisik dan lokasi sehingga dapat dilihat kecocokan penggunaan alternatif tersebut dengan zonasi lahan, building code dan peraturan AMDAL.

2. Aspek Legalitas Syar'i

Dalam aspek legalitas beberapa analisis yang dilakukan tidak bertentangan dengan syariat Islam, seperti dalam menganalisa building code dan AMDAL. Hal ini dikarenakan tidak ada unsur yang melanggar prinsip Islam. Adapun aspek-aspek yang perlu mendapatkan perhatian lebih adalah analisa pada status hak tanah dan zoning.

a. Status hak atas tanah

Penilaian dan analisis Status hak atas dilakukan dengan meninjau status hukum tanah wakaf tersebut berkaitan dengan keberadaan Akta Ikrar Wakaf (AIW) dan sertifikat tanah wakaf. Perlunya peninjauan terhadap AIW adalah sebagai bukti legalitas yang menekankan bahwa tanah tersebut benar-benar telah diwakafkan dan telah memiliki kekuatan hukum. Keberadaan bukti legalitas atau registrasi tanag wakaf sangatlah penting (Pasamai, Qamar, Qahar, \& Nuna, 2018). Pembuatan AIW ini dilaksanakan sesuai dengan ketentuan yang diatur dalam Pasal 17 sampai dengan pasal 21 UU No. 41 Tahun 2004 tentang Wakaf. AIW ini dibuat berdasarkan ikrar wakaf yang disampaikan oleh waqif dihadapan nadzhir dan Pejabat Pembuat Akta Ikrar Wakaf (PPAIW) serta dua orang saksi. Setalah itu barulah diproses sertifikat tanah wakaf. Sebagaimana yang diketahui, bahwa tanah yang telah diwakafkan haruslah tanah hak milik yang terbebas dari segala perikatan dan persengketaan agar tanah ini dapat dimanfaatkan dengan semaksimal mungkin bagi kemaslahatan umat. Oleh karena itu, keberadaan sertifikat ini juga perlu ditinjau untuk menghindari kemungkinan terjadinya sengketa atas tanah wakaf dengan ahli waris dari waqif di lain hari serta penyalahgunaan oleh pihak yang tidak bertanggung jawab. Di dalam AIW terdapat pernyataan kehendak waqif yang secara jelas menentukan penggunaan tanah wakaf tersebut untuk apa dan kepada siapa tanah wakaf ini diamanahi untuk dikelola.

b. Zoning

Analisis ini mengkombinasikan peraturan zonasi daerah dengan peruntukan tanah wakaf yang dinyatakan oleh waqif dalam ikrar wakafnya. Ini didasarkan pada peraturan perundang-undangan tentang perwakafan di Indonesia yang penyusunannya dilandasi oleh ketentuan syariat Islam dalam Al-Qur'an, Sunnah dan Ijtihad Ulama. Selain itu, yang perlu diperhatikan adalah mengatur tentang kebolehan syariat Islam dalam pemanfaatan dan pengembangan harta benda wakaf. Pengembangan dan

.


pemanfaatan yang dibolehkan atas tanah wakaf didasarkan kepada peruntukan tanah wakaf, kebutuhan umat dan manfaat yang dapat diberikan kepada umat. Sehingga pengembangan dan pemanfaatan untuk kegiatan produktif sangat dianjurkan selama semua model pengembangan dan pemanfaatan tidak melanggar ketentuan syariat Islam, seperti tempat perjudian (Qs.02:219, 05:90-91, HR. Bukhari, no. 4860; Muslim, no. 1647, HR. Ahmad, no. 2221; Abu Daud, no. 3488), menjual minuman beralkohol (Qs.02:219, 05:90-91, 16:67, HR. Ahmad, no. 2221; Abu Daud, no. 3488, HR. Bukhari, no. 2236; Muslim, no. 1581), pemotongan \& penjualan daging babi (Qs. 02:173, 05:03, 06:145, 10:115, HR. Ahmad, no. 2221; Abu Daud, no. 3488, HR. Bukhari, no. 2236; Muslim, no. 1581), dan lain sebagainya.

Berkaitan dengan permasalahan tanah wakaf yang tidak lagi dapat dimanfaatkan sebagaimana peruntukannya maka diperkenankan untuk menggunakan metode Ibdal dan Istibdal. Sebagaimana yang diketahui bahwa dibeberapa Negara, seperti Malaysia telah menggunakan metode ini untuk memaksimalkan penggunaan harta benda wakaf. Di Indonesia sendiri telah sedikit disinggung perihal penjualan dan penggantian harta wakaf dalam UU no. 41 Tahun 2006. Namun pelaksanaannya belum banyak sebab pada dasarnya perihal Ibdal dan Istibdal ini memiliki perbedaan pendapat diantara para Ulama dan pengetahuan masyarakat yang masih minim tentang metode ini. Namun dalam penggunaan metode tersebut juga diharapkan kehati-hatiannya agar tidak melenceng dari garis-garis ajaran Islam mengenai konsep wakaf itu sendiri serta tidak mengurangi manfaat yang dapat diberikan. Ini didasari oleh tindakan yang dilakukan oleh Umar bin Khattab ra. setelah mendengar bahwa Baitul Mal yang berlokasi di Kufah dibobol pencuri maka dipindahkanlah masjid di Tamarin dan menjadikan Baitul Mal ada di arah kiblat masjid (di depannya). Sedangkan tanahnya yang lama dijadikan sebagai pasar bagi para penjual kurma. (Ath-Thayyar, 2015 dan Az-Zuhaili, 2016).

\section{Aspek Finansial}

Aspek finansial memiliki 4 jenis analisa yang digunakan dalam penilaian alternatif pengembangan terpilih. Empat jenis analisa tersebut adalah perencanaan biaya investasi, perencanaan pendapatan, perencanaan pengeluaran dan uji kelayakan investasi syariah. Namun, tidak dibutuhkan uji kelaykan secara penuh untuk memperoleh kesimpulan penggunaan, hanya dibutuhkan analisis singkat berdasarkan kepada perkiraan biaya, perkiraan kasar atas pendapatan dan estimasi jangka waktu secara logis untuk mampu memutuskan penggunaan yang mana yang lebih menguntungkan dibandingkat yang lain. Adapun 
analisis dari aspek finansial pada HBU yang perlu mendapat perhatian agar dapat digunakan dalam menilai tanah wakaf terletak pada analisa perencanaan pengeluaran dan uji kelayakan investasi usaha.

a. Perencanaan Pengeluaran

Perencanaan ini selain memperhatikan biaya operasional vol. 2, No. 2, Desember 2019 , kegiatan usaha, biaya pemeliharaan properti usaha dan ${ }^{\text {Pp. 157-176, ISSN p:2622-4755 }}$ e.2622-4798 penggantian barang yang sudah rusak. Di dalam syariat Islam terdapat kewajiban untuk mengeluarkan dana zakat, infak dan sedekah. Zakat adalah harta yang wajib dikeluarkan oleh muzakki (orang yang wajib berzakat) yang jumlahnya sesuai dengan ketentuan syariah untuk diberikan kepada mustahiq/ orang yang berhak menerima zakat yang telah ditentukan dalam Qs. at-Taubah ayat 60 (PSAK 109). Perintah Allah SWT mengenai kewajiban berzakat termaktub dalam Qs. At-Taubah ayat 103 yang berbunyi:

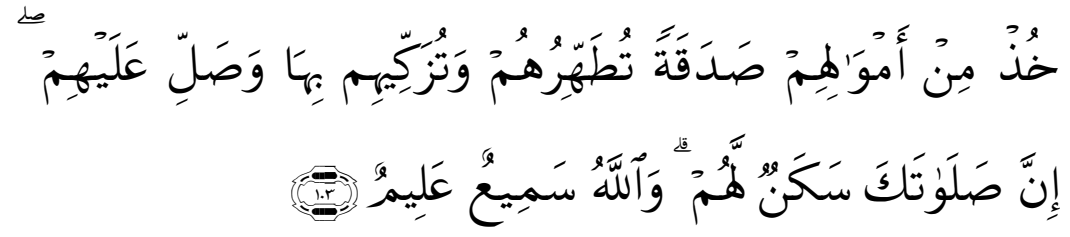

Artinya: Ambillah zakat dari sebagian harta mereka, dengan zakat itu kamu membersihkan dan mensucikan mereka dan berdoalah untuk mereka. Sesungguhnya doa kamu itu (menjadi) ketenteraman jiwa bagi mereka. dan Allah Maha mendengar lagi Maha mengetahui.

Dalam hal ini, zakat yang harus dikeluarkan adalah zakat penghasilan dari usaha, disesuaikan dengan bentuk usaha yang dijalankan/pengembangan penggunaan tanah wakaf yang diproduktifkan. Bila tanah wakaf kemudian digunakan sebagai tempat usaha untuk menjual barang-barang dagangan maka perlu diperhitungkan zakat barang dagangannya. Sedangkan bila tanah wakaf dibangun gedung atau rumah untuk disewakan maka perlu diperhitungkan zakat penghasilan terhadap jasa penyewaan gedung. Dana zakat ini harus dikeluarkan berdasarkan ketentuan syariat dengan memenuhi dua syarat, yaitu nishab dan haul. Ukuran nishab untuk zakat penghasilan dari usaha disamakan dengan zakat emas, yaitu 85 gram emas yang kemudian disetarakan dengan harga per gram emas di saat perhitungannya. Sedangkan untuk haulnya adalah 1 tahun, yaitu mulai dihitung setelah usaha berjalan selama 1 tahun. Adapun besarnya tarif zakat (qadar) yang harus dikeluarkan untuk penghasilan usaha adalah 2,5\% dari laba bersih sebelum dibagi hasilkan bila usaha tersebut menggunakan akad kerjasama (Syirkah).

Ihtifaz: Journal of Islamic Economics, Finance, and Banking 
Sedangkan infak dan sedekah adalah harta yang dikelaurkan secara sukarela oleh pemiliknya, baik yang peruntukannya dibatasi maupun tidak (PSAK 109). Besarnya tarif infak dan sedekah tidak terdapat ketentuan yang mengikatnya dan waktunya tidak dibatasi. Berbeda dengan zakat yang wajib, infak dan sedekah hukumnya sunnah. Terdapat banyak dalil yang menjadi landasan dalam berinfak dan sedekah, diantaranya adalah Qs. Adz-Dzariat: 19, Qs. Ali-Imran: 134, Qs. Al-Baqarah: 215, Qs. Al-Lail: 05.

\section{b. Uji Kelayakan Investasi Dalam Perspektif Islam}

Pada umumnya metode HBU menggunakan Net Present Value (NPV), Internal Rate of Return (IRR) dan Profitability Index (PI) dalam penilaian investasinya. Namun, ketiga perhitungan ini menjadikan tingkat suku bunga sebagai acuan dalam perhitungan yang mengarah pada konsep time value of money/positive time preference. Sehingga bunga menjadi alat ukur dalam menentukan nilai waktu modal dan investasi (Purnamasari, 2014). Padahal bunga bank itu identik dengan riba yang diharamkan dalam Islam. Sebagaimana firman Allah SWT dalam Qs. Al-Baqarah ayat 275 yang initnya adalah "....Allah menghalalkan jual beli dan mengharamkan riba......". Di Indonesia, perihal diperkuat dengan dikeluarkannya Fatwa Majelis Ulama Indonesia nomor 1 tahun 2004 tentang Bunga (Interest/Fa'idah) yang menyatakan keharaman bunga bank sebab telah memenuhi kriteria riba yang terjadi di zaman Rasulullah SAW, yaitu riba nasi'ah. Meskipun sebagian dari ulama dan para ahli tidak mempermasalahkan penggunaan tingkat suku bunga sebagai tolak ukur penilaian investasi. Sebab terdapat perbedaan saat interest rate digunakan sebagai tambahan/surplus dengan interest sebagai penghitung dalam rangka efisiensi (Ulgener; dalam Purnamasari, 2014).

Maka, akan lebih baik bila penilaian investasi yang dilakukan pada tanah wakaf sebagai instrument pembangunan dalam ekonomi Islam menghindari penggunaanya. Penyataan ini didukung oleh penelitian yang dilakukan M. Akram Khan (1987) yang menolak positive time preference karena penerimaan terhadap konsep ini akan mendorong legitimasi terhadap interest (bunga) yang identik dengan riba. Oleh karena itu, dalam analisis penilaian investasi yang digunakan pada HBU-I ini, menggunakan 2 instrument penilaian investasi yang dikembangkan oleh Agustina (2017) dalam jurnalnya yang mengkomparasikan analisis studi kelayakan Islam dan konvesnional. Kedua instrument penilaian tersebut didasarkan pada emas sebagai satuan hitungnya, yaitu Gold Value Method dan Gold Index Method. Adapun penjelasan mengenai ketiga metode ini, yaitu: 
1.) Analisis Gold Value Method (GVM)

Journal of

Analisis GVM adalah analisis penilaian investasi yang menggunakan prinsip bagi hasil baik dalam keadaan untung maupun rugi (profit and loss sharing) dan menggunakan standar emas yang didasarkan pada pendapat Ibnu Khaldun bahwa emas dan perak adalah ukuran nilai. Sebagaimana firman Allah SWT dalam Qs. At-Taubah ayat 34. (Agustina, 2017).

Berikut adalah rumus dari GVM:

$$
\begin{aligned}
& G V_{n}=\sum_{t}^{n}=\left(I S_{n} \div H E_{t}\right)-I N V \\
& I S_{n}=L B_{t} \times N_{t}
\end{aligned}
$$

\section{Keterangan:}

$I S_{n}=$ surplus investasi selama $\mathrm{n}$ tahun

$L B_{t}=$ laba bersih (aliran kas masuk)

$N_{t}=$ nisbah bagi hasil

$H E_{t}=$ laba bersih (aliran kas masuk)

INV = investasi awal

$\mathrm{n}$ = umur proyek

$\mathrm{t}$ = suatu periode

Berdasarkan pada analisis profit sharing dengan nisbah bagi hasil yang telah disepakati. Maka bila jumlah nilai pendapatan emasnya lebih besar dari jumlah investasi yang didasarkan pada harga emas (per gram) maka usaha tersebut dinyatakan layak dan sebaliknya.

2.) Analisis Gold Index Methode (GI)

Analisis GI adalah rasio antara Present Value emas dan present value emas dari pengeluaran aliran kas. Berikut rumus dari GI, yaitu:

$G I=\frac{\text { Total pendapatan emas }(\mathrm{gram})}{\text { Jumlah investasi awal }(\text { gram })}$

Bila nilai GI lebih beasr dari satu (GI > 1) maka usaha tersebut dinyatakan layak untuk dijalankan.

c. Analisis Produktivitas Maksimal

Analisis ini dilakukan sebagai rangkaian akhir dari analisis HBU-I, setelah alternatif penggunaan sementara di analisis finansial menunjukkan layak untuk dilakukan. Analisis ini 

dan tingkat pengembalian investasi. Berikut rumus untuk menentukan nilai lahan per meter persegi:

$$
\begin{gathered}
\text { Nilai } \frac{\text { Lahan }^{2}}{\mathrm{~m}}=\frac{\text { Nilai Properti* }- \text { Nilai Bangunan }}{\text { Total Luas lahan }} \\
\text { Nilai properti }=\frac{\mathrm{LB}}{\mathrm{HM}}
\end{gathered}
$$

\section{Keterangan:}

LB = laba bersih diakhir masa investasi

$\mathrm{HM}=$ persentase kenaikan harga emas

Nilai bangunan diasumsikan sebesar nilai investasi bangunan. Sebagaimana yang telah disinggung pada bab sebelumnya, bahwa penentuan nilai properti pada HBU konvensional menggunakan nilai MARR sebagai pembanding. Sedangkan pada HBU-I tidak lagi menggunakan MARR sebagai pembanding tetapi menggunakan tingkat pertumbuhan harga emas. Hal ini disebabkan nilai MARR menggunakan tingkat suku bunga sebagai acuan. Penggunan tingkat suku bunga dalam MARR bertentangan dengan prinsip kesyariatan. Oleh sebab itu, dengan memakai tingkat pertumbuhan harga emas dianggap dapat mengganti nilai MARR sebagai alternatif investasi yang tidak berbasis bunga. Selain itu, pertimbangan lainnya adalah nilai emas itu cenderung lebih stabil. Nilai MARR diganti dikarenakan nilai ini menggunakan tingkat suku bunga sebagai acuannya. Maka alternatif pengembangan dengan kenaikan nilai lahan tertinggi adalah alternatif penggunaan tertinggi dan terbaik dari tanah (berproduksi secara maksimal). Namun konsep nilai dalam Islam tidak sebatas nilai nominal yang tinggi tetapi nilai maslahah juga harus tinggi. Maka yang perlu diperhatikan adalah kembali kepada peruntukan awal tanah wakaf tersebut dengan menilai penggunaannya. Namun apabila di daerah tersebut peruntukan awal tanah wakaf tidak lagi memberikan manfaat (tidak lagi dibutuhkan) maka nadzhir boleh mengalihfungsikan tanah wakaf tersebut dengan peruntukan lain yang lebih dibutuhkan oleh masyarakat dan memberikan manfaat yang lebih banyak.

Contoh: Apabila di sekitar lokasi lahan tidak ditemukan tempat ibadah maka pembangunan tempat ibadah bisa menjadi opsi terbaik atas penggunaan atau pemanfaatan tanah wakaf tersebut. Sebab kebutuhan atas tempat ibadah tentu memiliki tingkatan yang lebih penting, sebagaimana firman Allah SWT dalam QS. Adz-Dzariat ayat 56 bahwa "manusia dan jin diciptakan untuk beribadah kepada-Nya". Sedangkan dalam kasus pengembangan properti, bentuk pemberdayaan yang sudah dilakukan bisa saja menjadi pemberdayaan terbaik dibandingkan dengan bentuk pengembangan lainnya. 


\section{KESIMPULAN}

Hasil dan diskusi dalam penelitian ini menunjukkan bahwa ada perbedaan tujuan antara metode HBU dan HBU-I dalam menentukan pemanfaatan lahan terbaik. Metode HBU menekankan pada pencapaian maksimalisasi laba individu. Sedangkan metode HBU-I bertujuan untuk menyediakan maslahah bagi manusia. Aspek penilaian yang harus $\mathrm{pp}$. 157-176, ISSN p:2622-4755 dipenuhi di dalamnya, mengalami perubahan dan penambahan indikator penilaian untuk digunakan dalam menilai tanah wakaf. Perbedaan antara dua bentuk metode ini adalah pada aspek fisik dan lokasi, para peneliti menambahkan panduan alternatif tentang penggunaan tanah wakaf berdasarkan lokasi. Pada aspek legalitas, peneliti mengganti indikator penilaian hak atas tanah, sehingga berdasarkan pada keberadaan akta janji wakaf dan sertifikat tanah wakaf. Pada indikator zonasi, peneliti menambahkan 5 sub indikator untuk dipertimbangkan, yaitu alokasi tanah wakaf, bentuk muamalah yang dilakukan dalam memanfaatkan tanah wakaf, kebutuhan masyarakat, manfaat yang dapat diberikan dan ibdal / istibdal. Dalam aspek keuangan, perbedaannya terletak pada indikator pengeluaran (pertimbangan pengeluaran untuk zakat, infaq, dana shadaqah) dan uji kelayakan investasi menggunakan metode nilai emas dan metode indeks emas. Aspek menentukan penggunaan terbaik didasarkan pada aspek material dan perhitungan nilai properti didasarkan pada persentase kenaikan harga emas.

\section{SARAN}

Penelitian ini masih memiliki banyak kekurangan dalam penyusunannya. Oleh karena itu, diharapkan dapat dilakukan penelitian lebih lanjut dan mendalam untuk setiap aspek penilaian dari metode HBU-I ini, sehingga penerapan nilai-nilai Islam dalam konsep ini dapat lebih menyeluruh dan metode ini dapat dimanfaatkan dengan baik.

\section{DAFTAR PUSTAKA}

Aji, Gunawan. 2015. "Studi kelayakan wakaf produktif (studi kasus pd blok pertokoan masjid al-fairus pekalongan)". Jurnal Wahana Akademika vol. 2 no. 1 April 2015: 21 - 36.

Ali;, N. M., Ahmad, R., \& Mahdzan, N. S. A. 2015." The need of an effective business model for waqf land development in Malaysia". 20th International Research Conferences on Business, Economics and Social Sciences, (I), 1-12.

Al-Hasan, Fahadil Amin. Agustus 2017. "Waqf Management in Indonesia Through Asset-Based Community Development (ABCD) Approach". International Journal of Social Science and Economic Research, ISSN: 2455-8834, Vol. 02, Issue 08, Hal. 4070-4087.

Antonio, Dr. Muhammad Syafi'i. 2001. Bank Syariah dari Teori ke Praktik. Jakarta: Gema Insani.

Ihtifaz: Journal of Islamic Economics, Finance, and Banking 
Appraisal Institute, 2008, The Appraisal of Real Estate, Third Edition, Appraisal Institute. Chicago, Illinois.

Arifin, Zainal. 2015. "Pertumbuhan Aset Wakaf dan Dilema Produktifitas". Jurnal Bimas Islam Vol.8 No. IV hal. 659-684.

Arifin, Jaenal. Desember 2014. "Problematika Perwakafan di Indonesia; Telaah Historis Sosiologis". Jurnal ZISWAF, Vol. 1, No. 2, 249-272.

Ath-Thayyar, dkk. 2015. Ensiklopedia Fiqh Muamalah Dalsm Pandangan 4 Mahzab. Cet. Ke-3. Yogyakarta: Maktabah Al-Hanif.

Az-Zuhaili, Wahbah. 2016. Fiqh Islam Wa Adillatuhu: Hak-hak anak, Wasiat, Wakaf dan Warisan. Cet. Ke-3. Jakarta: Gema Insani.

Badan Pusat Statistik (BPS). 2018. Statistik Daerah Kota Kupang 2015: Badan Pusat Statistik Kota Kupang.

Badan Pusat Statistik (BPS). 2018. Statistik Daerah Kota Kupang 2016: Badan Pusat Statistik Kota Kupang.

Badan Pusat Statistik (BPS). 2018. Statistik Daerah Kota Kupang 2017: Badan Pusat Statistik Kota Kupang.

Badan Pusat Statistik (BPS). 2018. Kota Kupang Dalam Angka 2015: Badan Pusat Statistik Kota Kupang.

Badan Pusat Statistik (BPS). 2018. Kota Kupang Dalam Angka 2016: Badan Pusat Statistik Kota Kupang.

Badan Pusat Statistik (BPS). 2018. Kota Kupang Dalam Angka 2017: Badan Pusat Statistik Kota Kupang.

Diamant, J. (2019, April 01). The countries with the 10 largest Christianpopulation and the 10 largest Muslim population. Retrieved April 16, 2019, from Factank: https://www.pewresearch.org/ fact-tank/2019/04/01/the-countries-with-the-10-largest-christianpopulations-and-the-10-largest-muslim-populations/

Direktorat Jendral Bimas Islam. Sistem Informasi Wakaf: Data Luas dan Lokasi Tanah Wakaf Kota Kupang Sampai dengan Tahun 2018. Depag RI. http://siwak.kemenag.go.id/\# ( Februari 2018)

Dogarawa, Ahmad Bello. 2009. "Poverty Alleviation through Zakah and Waqf Institutions: A Case for the Muslim Ummah in Ghana". Paper Presented at the First National Muslim Summit. Alfurqan Foundation from https://mpra.ub.uni-muenchen.de/23191/ diakses pada 10 Maret 2017.

Direktorat Pemberdayaan Wakaf. 2016. Bimas Islam Dalam Angka (Data Tahun 2012). Diakses pada 09 April 2017. http://simbi.kemenag. go.id/data-bida/\#sidebar

Dotzour, M. G., Grissom, T. V., Liu, C. H., \& Pearson, T. 1990. Highest and best use: The evolving paradigm. Journal of Real Estate Research, 5 (1), 17-32.

Furqon, Ahmad. April 2016. "Pengelolaan Wakaf Tanah Produktif (Studi Kasus Nazhir Badan Kesejahteraan Masjid Kota Semarang dan 
Yayasan Muslimin Kota Pekalongan)". Jurnal Al-Akam Vol. 26, No. 1, p-ISSN: 0854-4603; e-ISSN:2502-3209.

Grissom, Terry V., and Crocker H. Liu. 1994. "The Search for a Discipline: The Philosophy and the Paradigms." In Sthephen P. Jarchow, ed., Appraisal, Market Analysis, and Public Policy in Real Estate: Essay

in Honor of James A. Graaskamp. Boston: Kluwer and America Real Vol. 2, No. 2, Desember 2019, Estate Society.

Jonker, Jan, dkk. 2011. Metodologi Peneliian; Panduan untuk Master dan Ph.D. di Bidang Manajemen. Jakarta: Salemba empat.

Kinnard, William N. (1996). "New Thinking in Appraisal Theory." The Real Estate Appraisal 32(8).

Lubis, Suhrawardi K. 2010. Wakaf \& Pemberdayaan Umat. Jakarta: Sinar Grafika.

Mayangsari, Siti Nur Sarah dan Chirtiono Utomo. 2017. "Analisis Produktifitas Maksimum Penggunaan Lahan di Jalan Raya Meruyung Kota Depok". JURNAL TEKNIK ITS Vol. 6, No. 1, ISSN: 2337-3539.

Mohammad, M. T. S., Iman, A. H. M., \& Omar, I. (2005). An Ideal Financial Mechanism of The Waqf Properties in Malaysia. Development.

Mokhtar, S., \& Ibrahim, M. (2006). The Contemporary Methods of Waqf Land Development in Malaysia.

Mubarok, Jaih. (2008). Wakaf Produktif. Bandung: Simbiosa Rekatama Media.

Mubarok. Juni (2013). "Model Pengembangan Wakaf Produktif (Studi tentang Pengelolaan Wakaf pada Yayasan Muslimin Kota Pekalongan)". Jurnal Hukum Islam (JHI) Vol. 11, No. 1. ISSN (P): 1829-7382.

Muchti, Fajar dan Yulianto Achmad. (2009). Dualisme Penelitian Hukum Normatif \& Empiris. Yogyakarta: Pustaka Pelajar.

MAPPI. 2015. Kode Etik Penilaian dan Standar Penilai Indonesia (KEPI dan SPI). Jakarta.

Nurkaib. 2017. "Wakaf Perlu di Dukung untuk Perkuat Perekonomian Nasional". Diakses pada 05 Maret 2017. http://bwi.or.id/index.php/ in/publikasi/berita-mainmenu-109/1711-wakaf-perlu-didukunguntuk-perkuat-perekonomian-nasional.html

Omar, Hydzulkifli Hashim., Asmak, A. R., Ahmad Rizal, M., Azizi, A. B., \& Suhaila, A. K. (2013). "The Structuring for Development and Management Waqf Properties in Malaysia". The scope of meaning for the term $\mathrm{m}$ ā I has been extended to all to physical goo. Journal of Human Development and Communication, 2, 45-59.

Pasamai, S., Qamar, N., Qahar, A., \& Nuna, M. S. (2018). "The Nature of Waqf Land in Its Implementation Practices in Gorontalo Province". Journal Of Humanities And Social Science (IOSR-JHSS), 23(3), 81-90. https://doi.org/10.9790/0837-2303098190 
Pemerintah Indonesia. 2004. Undang-Undang No. 41 Tahun 2004 Yang Mengatur Tentang Perwakafan. Lembaran Negara R.I. Tahun 2004,

\section{IHTIFAZ - JIEFB}

Pitchay, A. A., Mohd Thas Thaker, M. A., Mydin, A. A., Azhar, Z., \& Abdul Latiff, A. R. (2018). "Cooperative-waqf model: a proposal to develop idle waqf lands in Malaysia". ISRA International Journal of Islamic Finance, 10(2), 225-236. https://doi.org/10.1108/IJIF-07-20170012

Prawoto, Agus. (2015). Teori dan Praktek Penilaian Properti. Edisi Ketiga, Cet. 1. Yogyakarta: BPFE.

Purnamasari. Desember 2014. "Time Value of Money Perspektif Syariah". ISSN Elektronik: 2442-2282, Vol 01, Issue 01, hal. 36-43.

Puspitasari, Ajeng Wahyu. 2017. "Optimizing Productive Land Waqf Towards Farmers Prosperity". Journal of Indonesian Applied Economics, Vol. 6, No. 1, 2017: 103-112.

Rozalinda. 2015. Manajemen Wakaf Produktif. Jakarta: PT. Raja Grafindo Persada.

Rozalinda. "The Economic Empowerment of the Ummah on the Basis of Productive Waqf in West Sumatra, Indonesia." International Journal of Nusantara Islam, Vol. 03 No. 01 - 2015; (33-46).

Vandell, Kerry D. and Carter, Charles C. 1990. "Graaskamp's Concept of Highest and Best Use". In Sthephen P. Jarchow, ed., Appraisal, Market Analysis, and Public Policy in Real Estate: Essay in Honor of James A. Graaskamp. Boston: Kluwer and America Real Estate Society. 